a Universidade Federal de Uberlândia, Núcleo de Pesquisa em Produtos Naturais, CEP 38400-902, UberlândiaMG, Brazil

${ }^{\mathrm{b}}$ Instituto Federal do Triângulo Mineiro, Núcleo de Bioprospecção em Produtos Naturais, CEP 38064-790, Uberaba-MG, Brazil

' Universidade de Franca, Laboratório de Pesquisa em Microbiologia Aplicada, CEP 14404-600, Franca-SP, Brazil ¿ Universidade Federal de Uberlândia, Instituto de Ciências Biomédicas, Laboratório de Triponossomatideos, CEP 38400-902, Uberlândia-MG, Brazil e Universidade Federal de Uberlândia, Instituto de Biotecnologia, CEP 38700-103, Patos de Minas-MG, Brazil

'Universidade Federal de Uberlândia, Instituto de Biotecnologia,

CEP 38408-100, Uberlândia-MG, Brazil.

\section{*E-mail: aquino@ufu.br}

Recebido em: 29 de Outubro de 2020

Aceito em: 1 de Julho de 2021

Publicado online: 25 de Outubro de 2021

\section{Chemical Composition of Seasonal Essential Oils from Psidium myrtoides O. Berg Leaves with Antimicrobial, Antiprotozoal, Antioxidant and Anti-inflammatory Potential Activities}

\author{
Composição Química de Óleos essenciais Sazonais de Folhas \\ de Psidium myrtoides O. Berg com Potencial Antimicrobiano, \\ Antiprotozoário, Antioxidante e Anti-inflamatório
}

\author{
Renieidy F. C. Dias, ${ }^{a}$ Allisson B. Justino, ${ }^{f}$ Evandro A. Nascimento, ${ }^{a}$ Sergio A. L. Morais, ${ }^{a}$ Alberto \\ de Oliveira, ${ }^{a}$ Luis C. S. Cunha, ${ }^{b}$ Carlos H. G. Martins, ${ }^{c}$ Mylla S. da Costa, ${ }^{d}$ Claudio V. da Silva, ${ }^{d}$ \\ Guilherme R. O. Freitas, ${ }^{e}$ Carla F. Lima, ${ }^{e}$ Tamiris Rodrigues, ${ }^{f}$ Flávio H. Barbosa, ${ }^{f}$ Tamyris de M. \\ Alves Martins, ${ }^{f}$ Carlos U. Vieira, ${ }^{f}$ Foued S. Espindola, ${ }^{f}$ Cássia R. Silva, ${ }^{f}$ Francisco J. T. Aquino $*$ (i)
}

Psidium species are traditionally used to treat bacterial agents and as an antiproliferative substance in human tumor cells. The current study investigated the seasonal essential oil composition of Psidium myrtoides $\mathrm{O}$. Berg (Myrtaceae) leaves from the rainy and dry periods as well as some potential bioactivities. The essential oils were obtained by hydrodistillation using a Clevenger-type apparatus, with $2.0 \mathrm{~L}$ round-bottomed flask, with $100 \mathrm{~g}$ and $1.0 \mathrm{~L}$ of distilled water, at $97^{\circ} \mathrm{C}$, for $4 \mathrm{~h}$. The obtained essential oils (EOs) were extracted with dichloromethane. The oil extraction procedure was performed in triplicate for each batch of leaves. The highest yield $(1.4 \pm 0.08 \%)$ was obtained in the rainy season oils. Twenty-six constituents were identified by gas-chromatography coupled to mass spectrometry (GC-MS) in the essential oils from the dry period and 22 constituents in the essential oils from the rainy season, all of them being hydrocarbons and oxygenated sesquiterpenes. The major compounds found in both periods, respectively, were $\beta$-caryophyllene $(26.23 \%$; $27.38 \%), \alpha$-humulene $(17.40 \% ; 16.18 \%), \beta$-caryophyllene oxide $(13.59 \% ; 20.66 \%)$, humulene epoxide-II $(6.09 \% ; 10.21 \%)$, and $\alpha$-copaene $(8.92 \% ; 7.11 \%)$. In general, no significant differences were observed in the chemical composition of essential oils, considering the seasonal effects and/or the status of the leaves. The antimicrobial and antiprotozoal activities were evaluated by the microdilution broth method and cytotoxic activity was carried out with Vero cells. The essential oils presented antibacterial activity against Streptococcus sanguinis $\left(200 \mu \mathrm{g} . \mathrm{mL}^{-1}\right)$, and antifungal activity against Candida glabrata $\left(46.87 \mu \mathrm{g} \cdot \mathrm{mL}^{-1}\right)$ in Minimal Inhibitory Concentration (MIC) assays. The essential oil obtained from fresh leaves collected in the rainy season (FLRS) presented the highest Selectivity Index (0.23) against the studied promastigote forms. Therefore, the rainy volatile oils were more effective against promastigote forms of Leishmania amazonensis $\left(31.8 \pm 5.74 \mu \mathrm{g} \cdot \mathrm{mL}^{-1}\right)$, while the dry volatile oils were more effective against Trypanosoma cruzi $\left(54.0 \pm 5.25 \mu \mathrm{g} \cdot \mathrm{mL}^{-1}\right)$. Furthermore, this study investigated the antioxidant (ORAC method) capacity, using Trolox as the standard, and anti-inflammatory potential (Drosophila melanogaster of GMR-GAL4 and UAS-eiger lineage) of these oils. Thus, dry season contributed to a volatile oil (DLDS) with higher ORAC antioxidant capacity $(2066.20 \pm 168.20 \mu \mathrm{mol}$ Trolox eq/g; $p<0.001)$ and showed no toxicity, as verified by the lineage survival test, being able to recover the eye area of the flies at $0.025-1.60 \mathrm{mg} . \mathrm{mL}^{-1}$ (essential oils from the dry season) and at $0.2-1.6 \mathrm{mg} . \mathrm{mL}^{-1}$ (essential oils from the rainy season) $(p<0.001)$. Therefore, the essential oils of $P$. myrtoides seems to be a potential therapeutical strategy against pathogens. In addition, our data suggest that the antioxidant and anti-inflammatory activities of the studied essential oils may be, at least in part, due to donation of hydrogen atoms and suppression of the Eiger pro-inflammatory cytokine, respectively.

Keywords: Psidium myrtoides; essential oil; terpenes; bioactivities assays

\section{Introduction}

The Myrtaceae family is generally considered as an important edible fruit family, which comprises around 121 genera and 3800-5800 species of woody shrubs or trees, mostly evergreen and distributed mainly in the tropics and subtropics. ${ }^{1}$ Psidium myrtoides O. Berg (Myrtaceae) is popularly known as "araçá-roxo" in the Cerrado biome, Brazil, having the appearance of trees of $6 \mathrm{~m}$ to $12 \mathrm{~m}$ in length and, sometimes reaching $20 \mathrm{~m}$. The bark of the trunk is exfoliating with papyraceous blades, and it presents opposite leaves with a size between $2.5 \mathrm{~cm}$ and $7.5 \mathrm{~cm}$. Its flower bearing bud opens with 4 flowers. The fruits, when ripe, present an 
atropurpureum color and are edible. ${ }^{2}$ The pharmacological properties of araçá species are attributed to their fruits and leaves, such as antioxidant, antiprotozoal, antibacterial, and antiproliferative effect in human tumor cells. ${ }^{2}$ However, its antioxidant and anti-inflammatory potential have not been explored yet.

The essential oils extracted from leaves of the Psidium genus are rich in terpene compounds. ${ }^{3,4}$ The $\beta$-caryophyllene is the most common (36.7\%) sesquiterpene, especially in the $P$. guajava and P. parvifolium species. Other terpene compounds usually present are $\alpha$-pinene $(12.9 \%)$, 1,8-cineole $(12.3 \%),(\beta)$-caryophyllene oxide $(12.0 \%)$, limonene (6.4\%), $\alpha$-humulene (4.4\%), $\alpha$-terpineol (3.8\%), $\beta$-cadinene $(3.7 \%)$, and $\beta$-selilene $(3.5 \%)$. The rate of sesquiterpenes in the genus Psidium is approximately $32 \%$, and most of these chemical compounds are obtained from the leaves (79\%). These compounds have well-described antioxidant and anti-inflammatory properties and may provide the Psidium myrtoides $\mathrm{O}$. Berg the ability to scavenge the reactive oxygen species and to modulate the inflammation processes..$^{5-8}$

In this scenario, the transgenic lineage of Drosophila melanogaster, the GMR-GAL4>UAS-eiger lineage, has been standardized as an animal model for evaluating the anti-inflammatory potential of different new molecules and natural products. ${ }^{9}$ The flies of this strain have an overexpression of the eiger gene, which is orthologous to the human tumor necrosis factor- $\alpha$ (TNF- $\alpha$ ), a pleiotropic inflammatory cytokine that acts as a central regulator of inflammation and cell death. ${ }^{10}$ The eiger gene expression is directed to the eye of the fly, resulting in the reduced eye phenotype due to cell death associated with the TNF- $\alpha$ cascade activation. ${ }^{9}$ Thus, the existence of members of the TNF family present in both human and Drosophila makes this organism an adequate model to elucidate the processes involved in the inflammatory pathway.

Therefore, this study aimed to elucidate the seasonal chemical composition of the essential oils obtained from the leaves of $P$. myrtoides, comparing them according to the period of collection (dry and rainy seasons), and to evaluate their in vitro antimicrobial, antiprotozoal, antioxidant, and anti-inflammatory potential using the $D$. melanogaster of the GMR-GAL4>UAS-eiger lineage.

\section{Materials and Methods}

\subsection{Plant materials}

The undamaged leaves of $P$. myrtoides were randomly collected from the top of single adult tree in the local area of Uberlândia (18 $56^{\prime} 45.3^{\prime \prime} \mathrm{S}$ and $\left.48^{\circ} 16^{\prime} 08.4^{\prime \prime} \mathrm{W}\right)$, Minas Gerais, Brazil. The collection was carried out in two different periods, in September 2017 (11:00 a.m.; dry season; without rainfall) and February 2018 (11:00 a.m., rainy season; average of $125 \mathrm{~mm}$ rainfall). There was no separation between young and old leaves. The dry leaves were dried at room temperature for $72 \mathrm{~h}$.

The authorization for collecting the plant was issued by the CNPq/SISGEN under the code A1247B0, and a voucher specimen is registered in the herbarium Uberlandense with the collection code HUFU65831.

\subsection{Essential oil extraction}

The extraction of the volatile oil using fresh or dried leaves was done by hydrodistillation using a Clevenger-type apparatus with $2.0 \mathrm{~L}$ round-bottomed flask, with $100 \mathrm{~g}$ of crushed samples and $1.0 \mathrm{~L}$ of distilled water, at $97^{\circ} \mathrm{C}$, for 4 h. ${ }^{11}$ The oil extraction procedure was performed in triplicate for each batch of leaves. The obtained essential oils (EOs) were extracted with dichloromethane; the organic phase was separated and dried with anhydrous sodium sulphate; filtered and kept in a closed vial under refrigeration $\left(-10^{\circ} \mathrm{C}\right)$ for further analysis. ${ }^{11}$ The percentage yield was calculated based on the dry mass of the initial sample, with this procedure being performed in triplicate.

\subsection{Analysis and identification of the constituents}

The oils were analyzed, and their constituents were identified by gas-chromatography coupled to mass spectrometry (Shimadzu, model GC17A/QP5010), equipped with a SPC-5 capillary column $30 \mathrm{~m} \times 0.25 \mathrm{~mm} \times 0.25 \mu \mathrm{m}$ film thickness). The GC-MS chromatograms for essential oils from the dry and rainy periods are shown in Figures $1 \mathrm{~S}$ and $2 \mathrm{~S}$ (Supplementary Material). The carrier gas was helium at a flow rate of $1 \mathrm{~mL} \cdot \mathrm{min}^{-1}$, detector and injector temperatures were $220{ }^{\circ} \mathrm{C}$ and $246{ }^{\circ} \mathrm{C}$ respectively, the injection volume was $1 \mu \mathrm{L}$, and the split ratio was $1: 20$. The oven temperature was programmed from $60^{\circ} \mathrm{C}$ to $246^{\circ} \mathrm{C}$, at $3{ }^{\circ} \mathrm{C} \mathrm{min}{ }^{-1}$ and the injected volume was $1 \mu \mathrm{L}$ of $5 \mu \mathrm{g} \cdot \mathrm{mL}^{-1}$ solution in dichloromethane.

The electron impact energy was set at $70 \mathrm{eV}$ and fragments from $40 \mathrm{~m} / \mathrm{z}$ to $650 \mathrm{~m} / \mathrm{z}$ were collected. The identification of the essential oil components was carried out by matching the spectra obtained with those stored in software libraries (Wiley7; Wiley229; Nist08; Nist08s; Nist27; Shim2205) and by comparing the calculated arithmetic index (AI) with the arithmetic index reported in the literature. ${ }^{12}$ Only peaks higher than with a match factors above $90 \%$ were considered. Authentic standards were used when necessary. Arithmetic indices were calculated using equation $\mathrm{AI}(\mathrm{X})=100 \mathrm{PzC}+100[(\mathrm{t}(\mathrm{X})-\mathrm{t}(\mathrm{Pz})) / \mathrm{t}(\mathrm{Pz}+1)-\mathrm{t}(\mathrm{Pz}))]$, based on the retention times $\left(\mathrm{R}_{\mathrm{t}}\right)$ of linear alkane standards $\left(\mathrm{C}_{8}-\mathrm{C}_{30}\right)$ which, by definition, have an $\mathrm{AI}$ equal to 100 times the number of carbon atoms. $\mathrm{X}=$ compound at time $\mathrm{t}$; $\mathrm{PzC}=$ number of carbon atoms of the alkane $\mathrm{Pz}$, which runs just before $\mathrm{X} ; \mathrm{Pz}+1=$ alkane running after $\mathrm{X}$. Quantification was obtained after normalization of the peak areas in the total ion chromatogram (TIC). Results represent average values of three replicates for each essential oil analysis. 
Only concentrations over 1.0\% (TIC-area) were considered. The identification was based on a comparison of the mass spectra obtained and those of the virtual libraries, and the AI obtained was compared with AIs of the NIST Standard Reference Data. ${ }^{12}$

\subsection{Anticandidal assay}

The microorganisms tested were Candida albicans (C. albicans) (ATCC 28366), Candida tropicalis (C. tropicalis) (ATCC 13803), and Candida glabrata (C. glabrata) (ATCC 15126) from the American Type Culture Collection (ATCC, Rockville MD@, USA). The assays were performed via the broth microdilution method using the standards recommended by the Clinical and Laboratory Standards Institute. ${ }^{13}$

The stock solutions were prepared by dissolving the essential oils in dimethyl sulfoxide (DMSO) (SigmaAldrich, Co) in a concentration of $192,000 \mu \mathrm{g} \cdot \mathrm{mL}^{-1}$. Dilutions were made using the standard RPMI 1640 medium, at $12,000 \mu \mathrm{g} . \mathrm{mL}^{-1}$. The inoculum was prepared using a spectrophotometric method (at $530 \mathrm{~nm}$ wavelength) and compared with a $0.5 \mathrm{McF}$ arland scale to obtain $6.0 \times 106 \mathrm{CFU} \mathrm{mL}^{-1}$. Then, the dilutions recommended by the CLSI were made with RPMI until the inoculums reached $1.2 \times 103 \mathrm{CFU} / \mathrm{mL} .^{13}$

The minimum inhibitory concentration (MIC) was determined using the 96-well microplates, where dilutions with final concentrations were made in the range from 1.46 to $3,000 \mu \mathrm{g} \cdot \mathrm{mL}^{-1}$. Amphotericin B was used as positive control, being diluted in broth at concentrations between 0.031 and $16.0 \mu \mathrm{g} \cdot \mathrm{mL}^{-1}$. The negative control (DMSO) was tested with concentrations ranging from $1 \%$ to $10 \%\left(\mathrm{v} \mathrm{v}^{-1}\right)$ and did not affect yeast growth. The added inoculum medium was used as a culture growth control. To validate the tests, the positive control Amphotericin B was tested against reference strains of Candida krusei (ATCC 6258) and Candida parapsilosis (ATCC 22019) in a range of MIC values from $0.25 \mu \mathrm{g} . \mathrm{mL}^{-1}$ to $2.00 \mu \mathrm{g} \cdot \mathrm{mL}^{-1} \cdot{ }^{13} \mathrm{After}$ incubation, $30 \mu \mathrm{L}$ of a $0.02 \%$ aqueous resazurin (Sigma ${ }^{\circledR}$ ) solution was added to each well and the microplates were incubated for additional $30 \mathrm{~min}$, for analysis of the results. Then, the minimum inhibitory concentration (MIC) was determined.

\subsection{Antibacterial activity}

The tested strains were obtained from the American Type Culture Collection (ATCC; Rockville, MD, USA). The following microorganisms were used in the evaluation of the antibacterial activity: Streptococcus mitis (ATCC 49456), Streptococcus mutans (ATCC 25175), Streptococcus sanguinis (ATCC10556), Agregatibacter actinomycetemcomitans (ATCC 43717), Actinomyces naeslundii (ATCC 19039), Porphyromonas gingivalis (ATCC 33277), Fusobacterium nucleatum (ATCC 25586), Staphylococcus aureus (ATCC 25923), Escherichia coli
(ATCC 25922), and Pseudomonas aeruginosa (ATCC 27853). The antibacterial activity of $P$. myrtoides was determined in triplicate by the verification of the minimum inhibitory concentration (MIC), using the microdilution broth method in 96-well microplates. ${ }^{13}$ The EOs were dissolved in dimethyl sulfoxide (DMSO, Sigma-Aldrich, St. Louis, USA) at $8000 \mu \mathrm{g} \cdot \mathrm{mL}^{-1}$, followed by a dilution in tryptic soy broth (TSB; Merck, Darmstadt, Germany) for aerobic microorganisms; and in Schaedler broth (BBL, Microbiology Systems, Cockeysville, MD) supplemented with hemin $\left(5.0 \mu \mathrm{g} . \mathrm{mL}^{-1}\right)$ and vitamin $\mathrm{K} 1\left(10.0 \mu \mathrm{g} \cdot \mathrm{mL}^{-1}\right)$, for anaerobic microorganisms. The concentrations tested ranged from $400 \mu \mathrm{g} \cdot \mathrm{mL}^{-1}$ to $25 \mu \mathrm{g} \cdot \mathrm{mL}^{-1}$. The final DMSO content was $4 \%\left(\mathrm{vv}^{-1}\right)$, and this solution was used as a negative control. The inoculum was adjusted for each organism to yield a cell concentration of $5 \times 10^{5}$ colony forming units $(\mathrm{CFU})$ per $\mathrm{mL}$. The microplates with the anaerobic microorganisms were incubated aerobically at $37^{\circ} \mathrm{C}$, for $24 \mathrm{~h}$. The anaerobic microorganisms were incubated for 48-72 $\mathrm{h}$ in an anaerobic chamber (Don Whitley Scientific Bradford, UK), at $5^{\circ} \mathrm{C}$. After that, resazurin (Acros Organics $\mathrm{NV}$, Geel, Belgium) in aqueous solution $\left(0.01 \% \mathrm{w} \mathrm{v}^{-1}\right)$ was added to the microplates to indicate the microorganism viability. Chlorhexidine dihydrochloride was used as a positive control. The negative control (DMSO) was tested with concentrations ranging from $1 \%$ to $10 \%\left(\mathrm{vv}^{-1}\right)$ which did not affect the bacterial growth. Sterility tests were performed for the TSB and Schaedler broths, control culture (inoculum), positive control, oils, and DMSO.

\subsection{Antiprotozoal activity}

The essential oils from $P$. myrtoides were dissolved in methanol and diluted with Dulbecco's Modified Eagle Medium (DMEM) to test their efficacy against Trypanosoma cruzi (T. cruzi) and diluted with BHI broth to evaluate their properties against Leishmania amazonensis (L. amazonensis), until a stock solution of $1280 \mu \mathrm{g} \cdot \mathrm{mL}^{-1}$ was obtained. ${ }^{13}$ The cell viability test was carried out, using tissue-culture trypomastigote (G strain) and a $L$. amazonensis promastigote stage (PH8 strain). The analysis was performed using a microdilution plate of 96 wells, obtained from the stock solution at concentrations of 1024, $512,256,128,64,32,16$, and $8 \mu \mathrm{g} \cdot \mathrm{mL}^{-1}$, not exceeding a value of $3 \%$ for methanol concentration. The final volume in each well was $100 \mu \mathrm{L}$ : $20 \mu \mathrm{L}$ of inoculum $\left(1 \times 10^{8}\right.$ parasites in $2 \mathrm{~mL}$ ) and $80 \mu \mathrm{L}$ of sample. Positive, negative, and control samples were prepared on each plate. The T. cruzi plate was incubated, for $48 \mathrm{~h}$, at $37{ }^{\circ} \mathrm{C}$, in a humidified atmosphere with $5 \% \mathrm{CO}_{2}$. Then, $4 \mu \mathrm{L}$ of $3 \mathrm{mM}$ resazurin in phosphate buffer solution (PBS) were added to each well as a developing solution, and incubated for $24 \mathrm{~h}$ under the same conditions, as outlined above. The $L$. amazonensis plate was incubated for $48 \mathrm{~h}$, at $25^{\circ} \mathrm{C}$, and then $2 \mu \mathrm{L}$ of a developing solution of $3 \mathrm{mM}$ resazurin in PBS was added to each well and incubated again for $24 \mathrm{~h}$, at $25^{\circ} \mathrm{C}$. At the 
end of this period, the absorbance $(594 \mathrm{~nm})$ was read using a microplate spectrophotometer. The half-maximal inhibitory concentration $\left(\mathrm{IC}_{50}\right)$ was calculated in triplicate using a dose-response graph with non-linear regression for each test.

\subsection{Cytotoxicity}

This test followed a procedure adapted from Martins et al.,${ }^{14}$ with the essential oil samples of $P$. myrtoides being dissolved in methanol, diluted in DMEM (Sigma Aldrich, USA), and supplemented until a solution of $1280 \mu \mathrm{g} \cdot \mathrm{mL}^{-1}$ was achieved. The cell viability test was performed with ATCC Vero cells (CCL 81; kidney fibroblasts from the African green monkey). The microplate dilution method was used for cytotoxicity evaluation. In each test, a solution was prepared containing $1 \times 10^{6}$ cells in supplemented DMEM. Then, $100 \mu \mathrm{L}$ of this solution was added into each well, and the plate was incubated for $6 \mathrm{~h}$, at $37{ }^{\circ} \mathrm{C}$, in a humidified atmosphere with $5 \% \mathrm{CO}_{2}$, causing adhesion to the well. Once cells were attached, the culture medium was removed and solutions of the samples were added, reaching the concentrations of 1,024, 512, $256,128,64,32,16$, and $8 \mu \mathrm{g} . \mathrm{mL}^{-1}$ by serial dilutions from the stock solution. The final concentration of methanol in each well did not exceed 3\%. Control negative (100\% lysed cells), solvent (methanol), and samples were also prepared. The microplates were incubated for $48 \mathrm{~h}$, at $37^{\circ} \mathrm{C}$, in a humidified atmosphere with $5 \% \mathrm{CO}_{2}$. Afterwards, a revealing solution of resazurin $3 \mathrm{mM}$ in PBS (Sigma Aldrich, St. Louis, Missouri, USA) was added to each well, and the plate was incubated again, for $24 \mathrm{~h}$, under the same conditions. Absorbance was read at $594 \mathrm{~nm}$ using a microplate spectrophotometer (Spectra Max190, Molecular Devices). The assays were performed in five replicates and the results of absorbance for each concentration tested were calculated according to the growth in the control. The cytotoxic concentration $\left(\mathrm{CC}_{50}\right)$ at which $50 \%$ of the cells are viable was calculated using a dose-response graph with non-linear regression for each test. The relationship between $\mathrm{CC}_{50}$ from the Vero cell line and $\mathrm{IC}_{50}$ from $L$. amazonensis was established by the Selectivity Index (SI) and calculated according to the equation proposed by Case et al. ${ }^{15}$

\subsection{Oxygen radical absorbance capacity (ORAC) antioxidant activity test}

The ORAC method was done according to Justino et al. (2018).$^{16}$ The essential oils of $P$. myrtoides diluted in methanol $\left(1 \mu \mathrm{g} \cdot \mathrm{mL}^{-1}\right)$ were incubated with $0.085 \mathrm{nM}$ fluorescein (diluted in $75 \mathrm{mM}$ sodium phosphate buffer, $\mathrm{pH} 7.4$ ), at room temperature, for $15 \mathrm{~min}$. The mixture received 2,2'-azobis (2-amidino-propane) dihydrochloride $(153 \mathrm{mM}$, diluted in $75 \mathrm{mM}$ sodium phosphate buffer, $\mathrm{pH}$ 7.4) and the loss of fluorescence intensity (485 nmex/528 nmex) (Perkin-Elmer LS 55, Waltham, MA, USA) was measured every $2 \mathrm{~min}$, for $90 \mathrm{~min}$, at $37^{\circ} \mathrm{C}$, by calculating the area under the curve.
The antioxidant capacity was determined using an analytical curve, constructed using Trolox as the standard ( $\mu$ mol trolox equivalents/g). Ascorbic acid was used as positive control and all analyses were done in triplicate.

\subsection{Anti-inflammatory potential assay}

\subsubsection{Acquisition of flies}

The transgenic strain of Drosophila melanogaster GMR-GAL4 (driver) > UAS-eiger (reporter) was obtained from Bloomington (Drosophila Stock Center - Indiana University), kept in the Genetics Laboratory of the Federal University of Uberlândia, kindly provided by professor Dr. Carlos Ueira. The drosophila host were kept in glass flasks containing a culture medium prepared with water $(150 \mathrm{~mL})$, yeast $(2.7 \mathrm{~g})$, soy flour $(1.5 \mathrm{~g})$, cornmeal $(10.95 \mathrm{~g})$, agar $(0.9 \mathrm{~g})$, glucose syrup $(11.55 \mathrm{~g})$, acid solution $(1.25 \mathrm{~mL})$, and Nipagin solution $(1.5 \mathrm{~mL})$, remaining in a BOD oven (SOLAB, Piracicaba, SP, Brazil), in a 12:12-h light/dark (12L:12D) photoperiods, at $25{ }^{\circ} \mathrm{C}$.

\subsubsection{Survival and inflammatory assays}

The survival and inflammatory assays with GMRGAL4>UAS-eiger were based on the model proposed by Igaki et al. (2002), ${ }^{9}$ with modifications, performed on larvae in the L3 stage of development. Briefly, adult flies were transferred to a laying medium composed of fresh biological yeast supplemented with sucrose, for $8 \mathrm{~h}$, to perform oviposition. After $72 \mathrm{~h}$, the new individuals in the L3 stage were collected and transferred to a culture medium containing $2 \mathrm{~g}$ of mashed potato (Yoki, Brazil), and $5 \mathrm{~mL}$ of the essential oils of P. myrtoides leaves collected in the dry season or in the rainy season $\left(0.025-1.60 \mathrm{mg} \cdot \mathrm{mL}^{-1}\right.$, diluted in $0.025 \%$ Tween 80 ). The treatments with water (negative control) or vehicle $(0.025 \%$ Tween 80$)$ were also tested. Each treatment used 40 larvae in the L3 stage. The development of the flies was monitored, and the number of individuals that reached the pupal and adult phases was recorded. The adult flies that hatched in the groups treated with essential oils and, in the control groups, were anesthetized with ether and fixed in $70 \%$ ethanol to preserve the morphology of the organisms, which were subsequently photographed with a stereoscopic microscope (Nikon SMZ 800), with $3 X$ zoom, coupled to a digital camera and using the IC Capture software. The eyes of each fly were photographed in right and left views, and the eye area, defined as the red area in the ocular region of the individual was selected and measured using the ImageJ software.

\subsection{Statistical analysis}

The statistical analyses and graphics were done using GraphPad Prism 6.0 software (GraphPad Software Inc., San Diego, CA, USA). The data were expressed as mean \pm standard error and the statistical significance of the difference was calculated using the unpaired t-test and one- 
way ANOVA, whereas the Dunnett's and Tukey's post-tests were employed for multiple comparisons. Values of $p<0.05$ were considered significant.

\section{Results and Discussion}

\subsection{Yield and chemical composition of the essential oils}

The essential oils of $P$. myrtoides were colorless and presented a characteristic citrus odor. In addition to the seasonal studies (Dry season-DS and Rainy Season-RS), the chemical composition of the essential oils was also evaluated according to the drying time (fresh leaves - FL and dried leaves for $72 \mathrm{~h}$ - DL), resulting in four essential oils. The yield of FLDS and DLDS essential oils were $1.08 \pm 0.22 \%$ and $0.77 \pm 0.22 \%$, respectively. The yield of FLRS and DLRS essential oils were $1.4 \pm 0.18 \%$ and $1.14 \pm 0.18 \%$, respectively.

The GC-MS chromatograms for the studied essential oils are shown in Figures 1S and 2S (Supplementary Material). Twenty-six constituents were identified by GC-MS in the essential oils from the dry period and 22 in the essential oils from the rainy period (Table 1). The main classes of compounds identified were sesquiterpene hydrocarbons and oxygenated sesquiterpenes. The major compounds of the essential oils were $\beta$-caryophyllene, $\alpha$-humulene, humulene epoxide II, $\alpha$-copaene, $\alpha$-bisabolol, and $\beta$-caryophyllene oxide. Recent studies demonstrated that essential oils extracted from the leaves of Psidium species, including Psidium myrtoides $\mathrm{O}$. Berg, are rich in terpene compounds. ${ }^{17}$ Despite the seasonal effects, the essential oil yield of P. myrtoides $\mathrm{O}$. Berg was similar, varying around $1.0 \%$, and being comparable to the other species of Psidium. ${ }^{18-22}$

The essential oil from fresh leaves sampled in the dry season suffered a variation in the concentration of its constituents when compared with the essential oil from dried leaves from the same season, but both oils did not present any qualitative loss of its chemical constituents, presenting 26 components (Figure 1S). However, the oils from fresh and dried leaves sampled in the rainy season experienced qualitative and quantitative loss in their chemical constituents, but the major compounds remained unchanged, resulting in 22 chemical compounds identified (Figure 2S).

In general, no significant differences were observed in the chemical composition of the essential oils, regarding seasonal effects and/or status of the leaves. Twenty-six essential oils were identified by GC-MS from the dry season and 22 as essential oils from the rainy season. The major essential oil compounds were $\beta$-caryophyllene, $\alpha$-humulene, humulene epoxide II, $\alpha$-copaene, $\alpha$-bisabolol, and $\beta$-caryophyllene oxide. The classes of compounds identified were sesquiterpenes hydrocarbons and oxygenated sesquiterpenes (Table 1) for all essential oils and the structure of the major compounds found are shown in Figure 1.
The concentrations of $\beta$-caryophyllene and $\beta$-caryophyllene oxide are quite similar in the essential oil from fresh leaves collected in the rainy season ( $18.02 \%$ and $20.66 \%$, respectively), but when the leaves were dried for $72 \mathrm{~h}$ the amount of B-caryophyllene oxide dropped dramatically (from $20.66 \%$ to $11.41 \%$ ). The major compound in all essential oils was $\beta$-caryophyllene, probably because of the direct sunlight exposure of the plant in a tropical region, and due to the greater humidity in the fresh leaves (50\% versus $16 \%$ in the dried leaves). This result can also be related to the elimination of substances when the leaves are dried, making some compounds more evident than the others, to the detriment of their availability on the surface or inside the leaf ${ }^{23}$ along with the higher solar exposure of leaves. ${ }^{21,24}$

\subsection{Antifungal and antibacterial activities}

The Candida species evaluated in this work are often involved with opportunistic infections, with 95\% of the bloodstream infections being caused by Candida species such as $C$. albicans, C. tropicalis, C. glabrata, and $C$. parapsilosis. These yeasts were resistant to at least one of the following drugs amphotericin B, fluconazole, and itraconazole. ${ }^{23}$ The MIC found for $C$. glabrata in the present study is significant since this yeast from the hospital environment presented one of the greatest resistances against fluconazole (64.7\%), according to Furlaneto et al. ${ }^{25}$ Others studies have shown that about $10 \%$ of C. glabrata present resistance to fluconazole, and about $52 \%$ are resistant to itraconazole. ${ }^{21,22}$ The EO of Blepharocalyx salicifolius, as example, with high sesquiterpene hydrocarbon content, was tested against different species of Candida and did not show activity in concentrations up to $5,000 \mu \mathrm{g} \mathrm{mL}{ }^{-1} .^{11}$ $\beta$-caryophyllene oxide and $\beta$-caryophyllene tested alone showed weak activity for $C$. glabrata and $C$. tropicalis and were inactive for $C$. albicans $\left(>3,000 \mu \mathrm{g} \cdot \mathrm{mL}^{-1}\right)$.

It is well known that essential oils rich in oxygenated terpenes can inhibit the development of Candida biofilms. ${ }^{26,27}$ Among the compounds found in the essential oil from P. myrtoides, $\beta$-caryophyllene oxide (11.41\%-13.59\%), $\beta$-bisabolol (0.89\%-2.65\%), and $\alpha$-copaene $(4.86 \%-8.92 \%)$ presented some anticandidal action in synergism with other oxygenated terpenes.

According to the literature, the antifungal and antibacterial activities of essential oils is classified as strong (up to $500 \mu \mathrm{g} \cdot \mathrm{mL}^{-1}$ ), moderate (between 500 and $1500 \mu \mathrm{g} \cdot \mathrm{mL}^{-1}$ ), and weak (higher than $1500 \mu \mathrm{g} \cdot \mathrm{mL}^{-1}$ ). ${ }^{15}$ The essential oil from dried leaves collected in the dry season showed strong activity for $C$. glabrata, with a MIC of $46.9 \mu \mathrm{g} . \mathrm{mL}^{-1}$, while the essential oils from fresh leaves sampled in the rainy and dry seasons, and dried leaves collected in the rainy season presented a strong effect against this microorganism, with MICs ranging from $187.5 \mu \mathrm{g} \mathrm{mL}^{-1}$ to $375.0 \mu \mathrm{g} \cdot \mathrm{mL}^{-1}$ (Table 2). The antifungal activities for C. tropicalis were moderate to weak with MICs ranging 


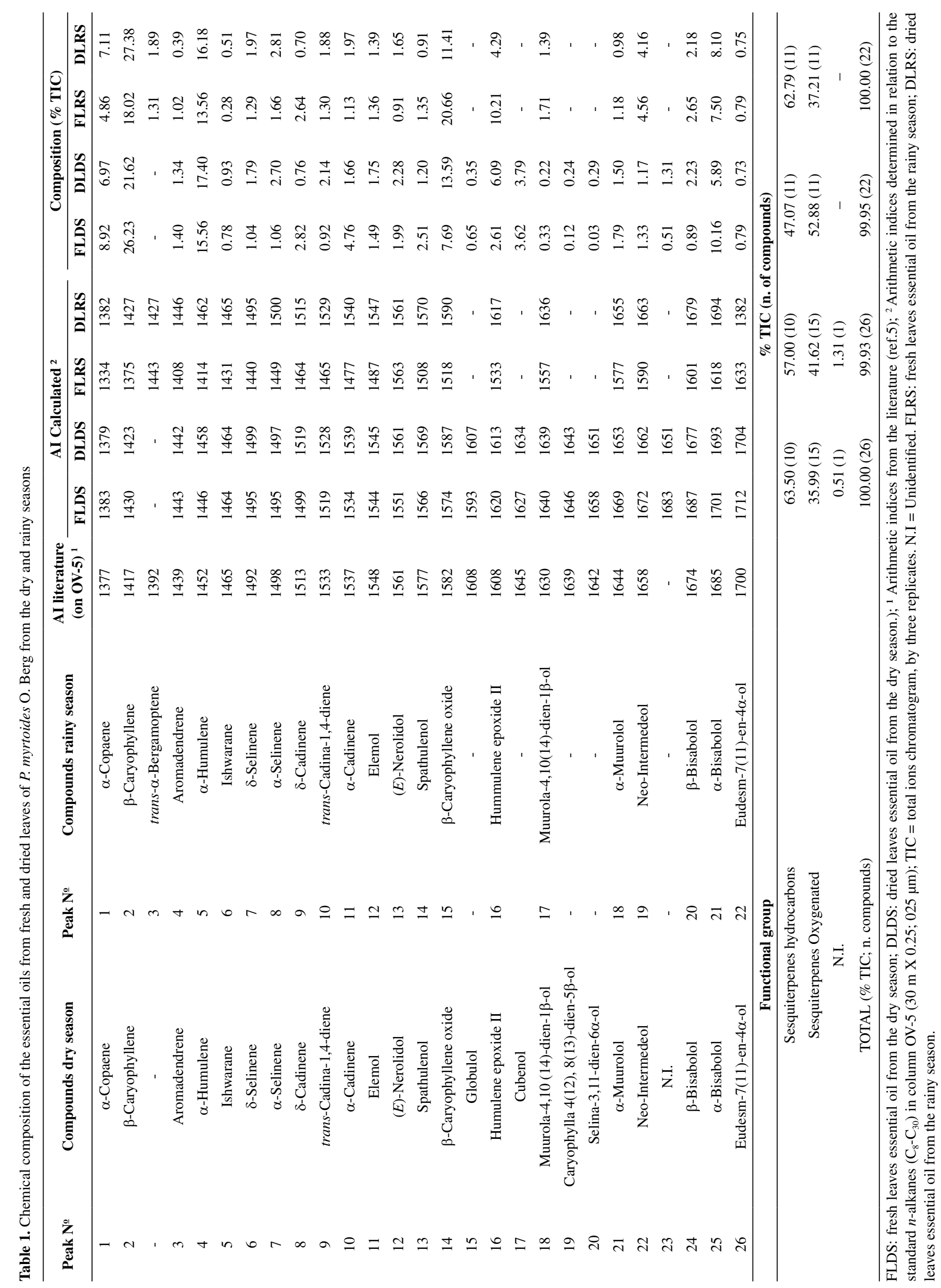



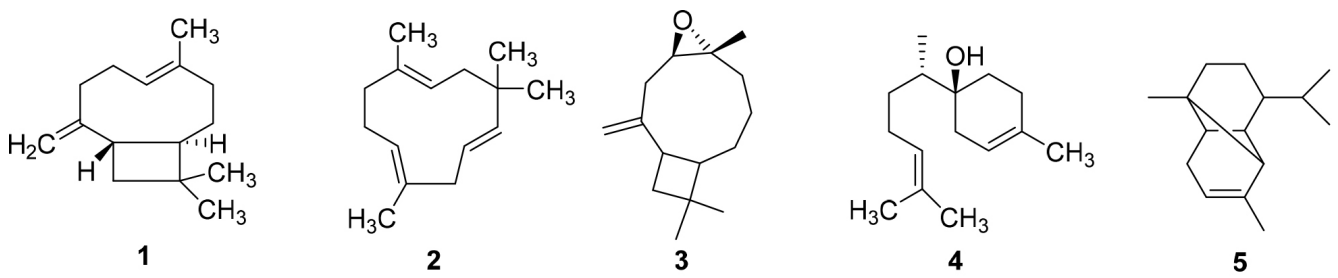

$\mathbf{1}=\beta$-Caryophyllene; $\mathbf{2}=\alpha$-Humulene; $\mathbf{3}$ = Caryophyllene oxide; $\mathbf{4}=\alpha$-Bisabolol; $\mathbf{5}=\alpha$-Copaene

Figure 1. Chemical structures of the major compounds identified as essential oils obtained from P. myrtoides

from $375 \mu \mathrm{g} \cdot \mathrm{mL}^{-1}$ to $3,000 \mu \mathrm{g} \cdot \mathrm{mL}^{-1}$, while for C. albicans the leaves had a weak effect on fungus, with MICs ranging from 3,000 $\mu \mathrm{g} \cdot \mathrm{mL}^{-1}$ to $1,500 \mu \mathrm{g} \cdot \mathrm{mL}^{-1}$.

Regarding antibacterial activity the essential oils from fresh and dried leaves sampled in the dry season (FLDS and DLDS) showed moderate activity against $S$. mutans $(400 \mu \mathrm{g}$. $\left.\mathrm{mL}^{-1}\right)$ and S. sanguinis $\left(200 \mu \mathrm{g} . \mathrm{mL}^{-1}\right)$. The essential oils from fresh and dried leaves collected in the rainy season (FLRS and DLRS) were active only against $S$. sanguinis $\left(200 \mu \mathrm{g} . \mathrm{mL}^{-1}\right)$ and none of the oils had any effect on S. mitis (Table 2).

\subsection{Antiprotozoal and cytotoxicity activities of the essential oils}

Antiprotozoal activity $\left(\mathrm{IC}_{50}\right)$ and cytotoxicity $\left(\mathrm{CC}_{50}\right)$ data were obtained from the cell viability tests. According to the results of Table 3, essential oils from fresh and dried leaves collected in the dry season presented the lowest $\mathrm{IC}_{50}$ values of $796.30 \pm 8.93 \mu \mathrm{g} . \mathrm{mL}^{-1}$ and $54.05 \pm 5.25 \mu \mathrm{g} \cdot \mathrm{mL}^{-1}$, respectively, for Trypanosoma cruzi. This indicates that for the DLDS a higher concentration is required to inhibit $50 \%$ of parasites.

Based on the in vitro assay results, it was possible to calculate the concentration that determined $50 \%$ of cell viability $\left(\mathrm{CC}_{50}\right)$ and relate it to the $\mathrm{IC}_{50}$ values for the calculation of the Selectivity Index (SI). A positive value represents higher selectivity against microorganisms than cellular toxicity, and a negative value, lower selectivity for microorganisms and higher cytotoxicity. ${ }^{15}$ Thus, FLDS is more toxic $\left(\mathrm{IC}_{50} 796.3 \pm 8.93\right)$ than selective for the parasite with negative selectivity index (SI) values.

Regarding the essential oils from fresh and dried leaves sampled in the rainy season, there was no inhibition against $T$. cruzi at the concentration tested. In the L. amazonensis assay, essential oils from fresh and dried leaves collected in the dry season presented no inhibitory activity against the

Table 2. Inhibitory effect on the growth of yeasts, aerobic, and anaerobic oral bacteria (MIC values, $\mu \mathrm{g} \cdot \mathrm{mL}^{-1}$ ) of the essential oils from P. myrtoides leaves collected in the dry and rainy seasons

\begin{tabular}{|c|c|c|c|c|c|c|c|}
\hline \multirow{3}{*}{ Microorganism } & \multicolumn{7}{|c|}{ MIC ( $\mu$ g.mL $\left.L^{-1}\right)$} \\
\hline & \multicolumn{7}{|c|}{ Samples } \\
\hline & FLDS & DLDS & FLRS & DLRS & OC & TC & Positive control \\
\hline \multicolumn{8}{|l|}{ Gram-positive } \\
\hline Streptococcus mutans & 400 & 400 & $>400$ & $>400$ & $>400$ & $>400$ & $0.92^{\mathrm{a}}$ \\
\hline Streptococcus mitis & $>400$ & $>400$ & $>400$ & $>400$ & $>400$ & $>400$ & $3.68^{\mathrm{a}}$ \\
\hline Streptococcus sanguinis & 200 & 200 & 200 & 200 & $>400$ & $>400$ & $0.92^{\mathrm{a}}$ \\
\hline A. actinomycetemcomitans & $>400$ & $>400$ & $>400$ & $>400$ & $>400$ & $>400$ & $0.46^{\mathrm{a}}$ \\
\hline Actinomyces naeslundii & $>400$ & $>400$ & $>400$ & $>400$ & $>400$ & $>400$ & $1.84^{\mathrm{a}}$ \\
\hline Staphylococcus aureus & $>400$ & $>400$ & - & - & $>400$ & $>400$ & $6.75^{\mathrm{b}}$ \\
\hline \multicolumn{8}{|l|}{ Gram-negative } \\
\hline Escherichia coli & $>400$ & $>400$ & - & - & $>400$ & $>400$ & $3.12^{\mathrm{b}}$ \\
\hline Pseudomonas aeruginosa & $>400$ & $>400$ & - & - & $>400$ & $>400$ & $12.5^{\mathrm{b}}$ \\
\hline Porphyromonas gingivalis & $>400$ & $>400$ & $>400$ & $>400$ & $>400$ & $>400$ & $3.68^{\mathrm{a}}$ \\
\hline Fusobacterium nucleatum & $>400$ & $>400$ & $>400$ & $>400$ & $>400$ & $>400$ & $1.84^{\mathrm{a}}$ \\
\hline \multicolumn{8}{|l|}{ Yeast } \\
\hline Candida albicans & 3000 & 3000 & 1500 & 1500 & $>3000$ & $>3000$ & $0.25^{\mathrm{c}}$ \\
\hline Candida glabrata & 187.5 & 46.87 & 187.5 & 375 & 750 & $>3000$ & $0.25^{\mathrm{c}}$ \\
\hline Candida tropicalis & 1500 & 1500 & 375 & 750 & $>3000$ & 750 & $0.12^{\mathrm{c}}$ \\
\hline
\end{tabular}

FLDS: fresh leaves essential oil from the dry season; DLDS: dried leaves essential oil from the dry season; FLRS: fresh leaves essential oil from the rainy season; DLRS: dried leaves essential oil from the rainy season. Positive control: ${ }^{\mathrm{a}}$ Chlorhexidine dihydrochloride; ${ }^{\mathrm{b}} \mathrm{Chloramphenicol;}{ }^{\mathrm{c}} \mathrm{Anfhotericin} \mathrm{B}$. CO: $\beta$-Caryophyllene oxide. TC: $\beta$-caryophyllene. Bacteria control by protocol M11-A8 CLSI (2012): B. fragilis (MIC $\left.0,73 \mu \mathrm{g} \mathrm{mL}{ }^{-1}\right) ;$ B. thetaiotaomicron (MIC $1.47 \mu \mathrm{g} \mathrm{mL}^{-1}$ ); Yeast control by protocol M27-A3 CLSI (2008): C. krusei (MIC $1.0 \mu \mathrm{g} \mathrm{mL}^{-1}$ ); C. parapsilosis (MIC $0.5 \mu \mathrm{g} \mathrm{mL}{ }^{-1}$ ) 
parasite at the concentration tested. Essential oils from fresh and dried leaves sampled in the rainy season presented low $\mathrm{IC}_{50}$ values. The results obtained for all volatile oils tested were correlated by calculating the SI (Table 3). Based on the in vitro assay results, it was possible to calculate the concentration that determined $50 \%$ of cell viability $\left(\mathrm{CC}_{50}\right)$, and to relate it with $\mathrm{IC}_{50}$ values for the calculation of the selectivity index (SI). A positive value represents higher selectivity against microorganisms than cellular toxicity, and a negative value, lower selectivity for microorganisms and higher cytotoxicity. ${ }^{15}$

Regarding antiprotozoal activity $\left(\mathrm{IC}_{50}\right)$, the essential oils from fresh and dried leaves from the dry season presented inhibitory activities against trypomastigote forms of $T$. cruzi but not to the promastigote forms of L. amazonensis. The opposite occurred with the essential oils from rainy season leaves (Table 3). According to Chibale et al. ${ }^{28}$ the lower the $\mathrm{IC}_{50}$ value (inhibitory concentration of $50 \%$ of the protozoa) the higher was the antiprotozoal activity. The results in this study showed that the volatile oils from fresh leaves of $P$. myrtoides $\mathrm{O}$. Berg collected in the rainy season were the most effective against the promastigote forms of L. amazonensis $\left.(31.8 \pm 5.74) \mu \mathrm{g} \cdot \mathrm{mL}^{-1}\right)$, followed by dried leaves from the same season $\left.(55.7 \pm 7.86) \mu \mathrm{g} \cdot \mathrm{mL}^{-1}\right)$. The antiprotozoal activity of the essential oils depended on the type of terpenes, since they determine the interaction between the volatile oils with the cell hydrophobic membrane of the protozoa. ${ }^{29}$ However, some controversies persist regarding the efficacy of terpenes on the antiprotozoal activity. While monoterpenes are more effective than sesquiterpenes against the forms of $L$. amazonensis ${ }^{29,30}$ the inhibition of protozoa results from the action of sesquiterpenes (i.e. $\alpha$-bisabolol). Other sesquiterpene compounds exert trypanosomicidal activity in vivo and in vitro, like $(E)$-nerolidol ${ }^{31}$ and $\beta$-caryophyllene ${ }^{13,30,32}$ compounds also found in this study.
The cytotoxicity test, using Vero cells, revealed that all oils were toxic to the cells, which means that they contained few promising compounds for isolation and to be used against $T$. cruzi and L. amazonensis (Table 3). Moreover, positive SI values were found in the oils obtained from dried leaves sampled in the dry season as well as from dried and fresh leaves collected in the rainy season, representing a higher selectivity against microorganisms and low toxicity to Vero cells lineage. Negative SI values found in the fresh leaves collected in the dry season presented a higher toxicity to Vero cells and lower selectivity to the trypomastigote forms..$^{14}$ Despite the low SI values, the oils were selective to inhibit the parasite. Within this context, the oils from dried leaves sampled in the dry season as well as from dried and fresh leaves from the rainy season could be a promising agent for the treatment of leishmaniasis and Chagas disease.

Although these studies have been done with the same species, this activity difference may be explained by qualitative and quantitative variations in the chemical composition of the oils, as well as the consequence of seasonality and different collection regions. ${ }^{33,34}$

\subsection{In vitro total antioxidant capacity of the essential oils from the leaves of $P$. myrtoides}

The essential oils from leaves collected both in the dry and rainy seasons presented antioxidant properties according to the ORAC method (Table 4). The dry season contributed to a higher antioxidant capacity of the essential oils when compared with the rainy season $(p<0.001)$.

The antiradical activity of essential oils is mainly based on the hydrogen-donating properties of terpenes, corroborating the ORAC results for the essential oils of P. myrtoides. Furthermore, as expected, the essential oils extracted from leaves collected in the dry season showed a

Table 3. Antiprotozoal activities $\left(\mathrm{IC}_{50}\right)$, Cytotoxicity $\left(\mathrm{CC}_{50}\right)$, and Selective Index (SI) for essential oils of P. myrtoides

\begin{tabular}{lcccc}
\hline Sample & $\begin{array}{c}\text { Cytotoxicity } \\
\text { (Vero cells) } \\
\mathbf{C C}_{\mathbf{5 0},}, \boldsymbol{\mu g} \cdot \mathbf{m L}^{-1}\end{array}$ & $\begin{array}{c}\text { Trypanosoma cruzi } \\
\mathbf{I C}_{\mathbf{5 0}}, \boldsymbol{\mu g . \mathbf { m L } ^ { - 1 }}\end{array}$ & $\begin{array}{c}\text { Leishmania amazonensis } \\
\mathbf{I C}_{\mathbf{5 0}}, \boldsymbol{\mu g} . \mathbf{m L}^{\mathbf{1}}\end{array}$ & SI \\
\hline FLDS-EO & $58.99 \pm 10.41$ & $796.30 \pm 8.93$ & No toxic & -1.13 \\
DLDS-EO & $71.77 \pm 6.41$ & $54.05 \pm 5.25$ & No toxic & 0.12 \\
FLRS-EO & $53.79 \pm 6.55$ & No toxic & $31.80 \pm 5.74$ & 0.23 \\
DLRS-EO & $66.57 \pm 1.69$ & No toxic & $55.70 \pm 7.86$ & 0.08 \\
\hline
\end{tabular}

FLDS-EO: fresh leaves essential oil from the dry season; DLDS-EO: dried leaves essential oil from dry season; FLRS-EO: fresh leaves essential oil from the rainy season; DLRS-EO: dried leaves essential oil from rainy season

Table 4. Antioxidant capacity analysis using the ORAC method for the essential oils from the dried leaves from P. myrtoides collected in the dry and rainy seasons

\begin{tabular}{|c|c|c|}
\hline \multirow{2}{*}{ Antioxidant capacity } & \multicolumn{2}{|c|}{ Essential oils } \\
\hline & DLDS & DLRS \\
\hline ORAC ( $\mu$ mol Trolox eq/g) $)^{*}$ & $2066.20 \pm 168.20$ & $1144.90 \pm 38.30^{* * *}$ \\
\hline
\end{tabular}


higher antioxidant ability, which may be explained by the higher concentration of terpenes when compared with the essential oils from rainy season leaves. ${ }^{5,6,7}$

\subsection{Anti-inflammatory potential of the essential oils from the leaves of $P$. myrtoides}

The use of plants with medicinal properties as antioxidant and anti-inflammatory agents has gained prominence in the control and treatment of acute and chronic inflammatory conditions. Plant-derived terpenes, specifically sesquiterpenes, have anti-inflammatory effects, with suggested modulation of the TNF- $\alpha$ and nuclear transcription factor-kappa B (NF- $\kappa \mathrm{B})$ signaling pathway. ${ }^{8}$ Our results demonstrated that the cell death activity induced by the overexpression of the eiger gene (TNF- $\alpha$ ) in the eyes of the flies was reduced through the chronic exposure of L3 larvae to the essential oils, showing that the treatment has the ability to inhibit the activation of the induced c-Jun N-terminal kinase pathway by the pro-inflammatory cytokine..$^{9,10}$ The treatments with the essential oils from $P$. myrtoides leaves sampled in the dry and rainy seasons,

a

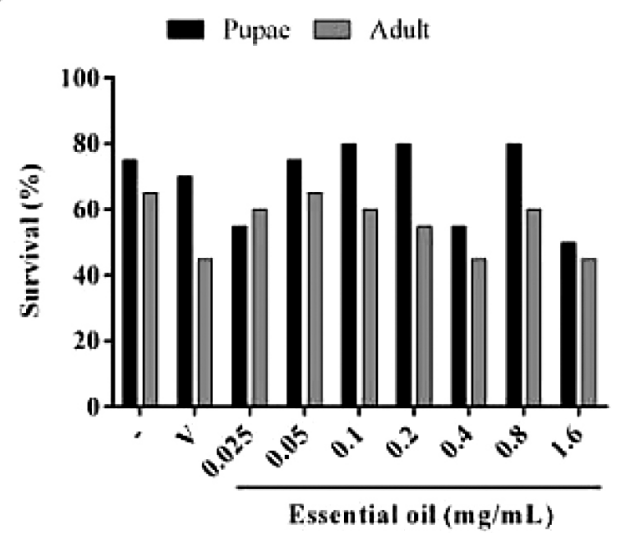

$\mathrm{c}$

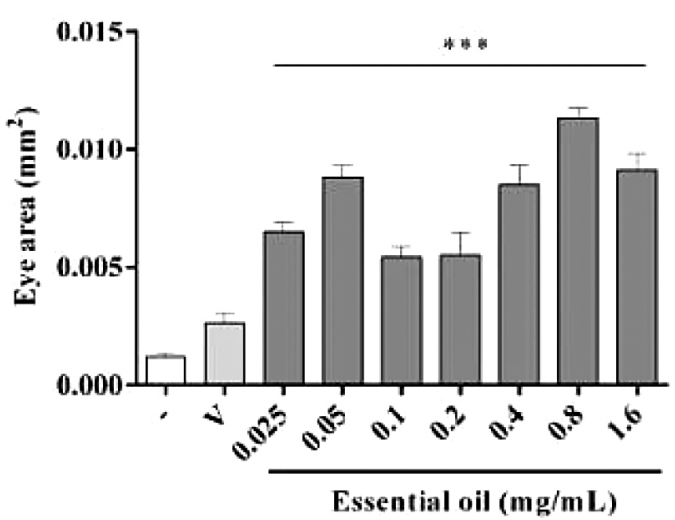

as well as with water and vehicle, were carried out with 40 L3 larvae, with the survival rate of the flies shown in the Figure 2.

Although the essential oils from leaves collected in the dry season showed low toxicity for the pupae and adult flies at $1.6 \mathrm{mg} \cdot \mathrm{mL}^{-1}$, there was no change in the survival pattern of the pupae and adult flies treated with the essential oils, only with water, or with the vehicle (Figures $2 \mathrm{a}$ and $2 \mathrm{~b}$ ).

This study also revealed the in vitro antioxidant properties of the $P$. myrtoides dried leaves as well as the ability to recover the eye area of a transgenic strain of Drosophila melanogaster. ${ }^{16,35-38}$

Studies on medicinal plants have shown a correlation between the antioxidant and anti-inflammatory properties..$^{39,40}$ Therefore, this study investigated the anti-inflammatory potential of the essential oils in a transgenic strain of D. melanogaster GMR-GAL4> UAS-Eiger. This fly presents a cytokine that is orthologous to the proinflammatory cytokine TNF- $\alpha$ (Eiger in D. melanogaster) and its respective receptor. ${ }^{41}$

TNF- $\alpha$ is a key cytokine in different inflammatory diseases and there are clinical therapies focused on its

b

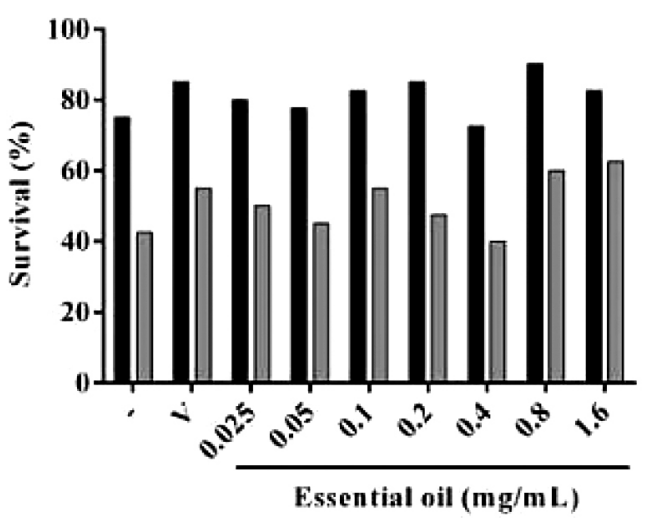

$\mathrm{d}$

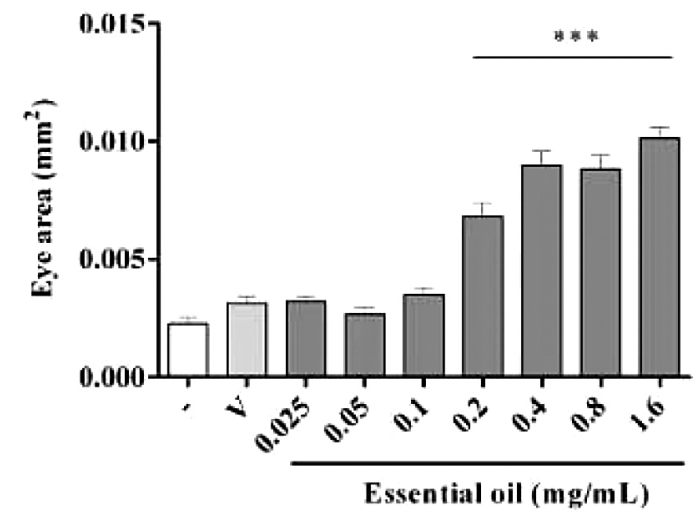

Figure 2. Survival of the transgenic strain of Drosophila melanogaster GMR-GAL4> UAS-eiger submitted to a treatment with essential oils of Psidium myrtoides extracted from dried leaves collected in the dry (a) and rainy (b) seasons $\left(0.025-1.6 \mathrm{mg} \mathrm{mL}^{-1}\right)$ and quantification of the eye area of the flies treated with essential oils of $P$. myrtoides extracted from dried leaves from the dry (c) and rainy (d) seasons $\left(0.025-1.6 \mathrm{mg} \mathrm{mL}^{-1}\right)$. Columns represent the mean \pm standard error. Note: -: control treatment with water; V: treatment with vehicle $(0.025 \%$ Tween 80$)$. Oneway ANOVA followed by Dunnett as post-test, ${ }^{* * *} p<0.001$ compared with the control group (-). Note: -: control treatment with water; V: treatment with vehicle $(0.025 \%$ Tween 80$)$ 
control. ${ }^{41-43}$ Additionally, the use of fruit flies as Drosophila for research is in accordance with the $3 \mathrm{R}$ 's rule of reduction, replacement, and refinement, making this an excellent biological model for inflammation analysis. In accordance with our hypothesis, a partial recovery of the eye area was observed in adult flies treated with the $P$. myrtoides essential oils compared to untreated flies, both for oil extracted during the dry and rainy periods, indicating the inhibition of the eiger gene's action (Figure 3S, Supplementary Material).

The flies treated only with water or vehicle (Figures $3 \mathrm{~S}$-a and 3S-b, respectively) did not present ocular recovery. However, the treatment with all concentrations of the essential oils from leaves sampled in the dry season (Figure 3S-c) presented an increase in the eye area $(p<0.001)$ when compared with the treatment with the control (water) or vehicle. Regarding the essential oils collected in the rainy season, concentrations above $0.2 \mathrm{mg} \cdot \mathrm{mL}^{-1}$ induced an increase in the eye area of the flies (Figure 3S-d) $(p<0.001)$.

As expected, and in accordance with the antioxidant test results, the eye recovery effect was observed for all concentrations tested of the essential oils from leaves collected in the dry season $\left(0.025-1.6 \mathrm{mg} \cdot \mathrm{mL}^{-1}\right)$, while only the highest concentrations of the essential oils from rainy season leaves (Figures 3S-e and 3S-f) presented antiinflammatory activity $\left(0.2-1.6 \mathrm{mg} \cdot \mathrm{mL}^{-1}\right)$. Furthermore, the essential oils showed no toxicity to the transgenic strain of D. melanogaster GMR-GAL4> UAS-Eiger, as verified by the lineage survival test.

A study conducted by Fernandes et al. (2007) also revealed the anti-inflammatory potential of the sesquiterpenes $\alpha$-bisabolol, $\beta$-caryophyllene and $\alpha$-humulene present in the essential oils in reducing the TNF- $\alpha$ release, in the paw edema of rats. ${ }^{5,44}$ Therefore, since these substances were able to downregulate the cytokine expression and secretion, this finding represents a very promising alternative to be used as a treatment of inflammatory-related diseases.

\section{Conclusions}

The essential oils from $P$. myrtoides leaves collected in the dry and rainy seasons presented no significant differences in the quantitative and qualitative profile of volatile constituents and, apparently, did not to affect nether the principal components or the biological activities. In general, the essential oils showed strong to moderate anticandidal activity for $C$. glabrata. In the antiprotozoal assay, the seasonal essential oils presented inverted results against two studied parasites. While the essential oils from dry season leaves presented antiprotozoal activities against T. cruzi, the essential oils from the rainy season exhibited antiprotozoal activities against $L$. amazonensis parasites. Additionally, the essential oils presented antimicrobial efficacy only against $S$. sanguinis. The sesquiterpenoids present in all the essential oils from $P$. myrtoides showed a synergistic potential bioactive ability.

In summary, our results supported the antioxidant and anti-inflammatory effects of the essential oils extracted from leaves of $P$. myrtoides, which vary according to the seasonal period, suggesting that these effects were activated, at least in part, by suppressing the eiger gene, which is orthologous to the human pro-inflammatory cytokine TNF- $\alpha$.

Thus, P. myrtoides, a plant species from a global biodiversity hotspot (Brazilian Savanna) with potential source of bioactive compounds that offer combined antimicrobial, antiprotozoal, and antioxidant properties, also presents an anti-inflammatory action for further in vivo inflammation models.

\section{Acknowledgments}

The authors gratefully acknowledge the Institute of Biotechnology and the Institute of Chemistry of the Federal University of Uberlândia for infrastructural support. They also thank for the fellowships granted by the Brazilian National Council for Scientific and Technological Development (CNPq), Higher Education Personnel Improvement Coordination (CAPES, DIAS, R. F. C., Scholarship Finance Code 001), and by the Foundation for Research Support of the State of Minas Gerais (FAPEMIG, APQ-01612-18). The F.S.E. received financial support by the CNPq/FAPEMIG from resources of the INCT-TeraNano - UFU. The authors are also grateful to Rayssa Ferreira Zanatta (UNITAU/FAOA-SP) for making Figure 3S.

\section{References}

1. Araújo F.F.; Neri-Numa I. A.; Farias, D. P.; Cunha, G. R. M. C.; Pastore, G. M.; Wild Brazilian species of Eugenia genera (Myrtaceae) as an innovation hotspot for food and pharmacological purposes (Review). Food Research International 2019, 121, 57. [CrossRef] [ [PubMed]

2. Oliveira, E. F.; Bezerra, D. G.; Santos, M. L.; Rezende, M. H. J.; Paula, A. M.; Leaf morphology and venation of Psidium species from the Brazilian savanna. Revista Brasileira de Farmacognosia 2017, 27, 407. [CrossRef]

3. Kumari, S.; Pundhir, S.; Priya, P.; Jeena, G.; Punetha, A.; Chawla, K.; Jafaree, Z. F.; Mondal, S.; Yadav, G.; EssOilDB: A database of essential oils reflecting terpene composition and variability in the plant kingdom, Database 2014, 2014, 1. [CrossRef] [PubMed]

4. Scur, M. C.; Pinto, F. G. S.; Pandini, J. A.; Costa, W. F.; Leite, C.W.; L. G.; Temponi, Antimicrobial and antioxidant activity of essential oil and different plant extracts of Psidium cattleianum Sabine. Brazilian Journal of Biology 2016, 76, 101. [CrossRef] [PubMed]

5. Fernandes, E. S.; Passos, G. F.; Medeiros, R.; da Cunha, F. M.; Ferreira, J.; Campos, M. M.; Calixto, J. B.; Anti- 
inflammatory effects of compounds alpha-humulene and (-)-trans-caryophyllene isolated from the essential oil of Cordia verbenacea. European Journal Pharmacology 2007, 569, 228. [CrossRef] [PubMed]

6. Gonzalez-Burgos, E.; Gomez-Serranillos, M. P.; Terpene compounds in nature: a review of their potential antioxidant activity. Current Medicinal Chemistry 2012, 19, 5319. [CrossRef] [Pubmed]

7. Grassmann, J.; Terpenoids as plant antioxidants. Vitamins \& Hormones 2005, 72, 505. [CrossRef] [PubMed]

8. De las Heras, B.; Hortelano, S.; Molecular basis of the antiinflammatory effects of terpenoids. Inflammation \& Allergy - Drug Targets 2009, 8, 28. [CrossRef][PubMed]

9. Igaki, T.; Miura, M.; The Drosophila TNF ortholog Eiger: emerging physiological roles and evolution of the TNF system. Seminars in Immunology 2014, 26, 267. [CrossRef] [PubMed]

10. Esposito, E.; Cuzzocrea, S.; TNF-alpha as a therapeutic target in inflammatory diseases, ischemia-reperfusion injury and trauma. Current Medicinal Chemistry 2019, 16,3152. [CrossRef] [PubMed]

11. Furtado, F. B.; Borges , B. C.; Teixeira, T.L.; Garces , H. G.; Junior, L. D. A.; Alves, F. C. B.; Silva, C. V. D.; Junior, A. F.; Chemical Composition and Bioactivity of Essential Oil from Blepharocalyx salicifolius, International Journal Molecular Sciences 2018, 19, 1. [CrossRef] [PubMed]

12. Adams, R. P.; Identification of Essential Oil Components by Gas Chromatography/Mass Spectrometry, 4th ed., Allured Pub Corp: Carol Stream, IL, 2007.

13. CLSI. Reference method for broth dilution antifungal susceptibility testing of yeasts, in CLSI Document M27-A3. 34th ed. Clinical and Laboratory Standards Institute; Wayne, PA, 2008. [Link]

14. Martins, M. M.; Aquino, F. J. T.; De Oliveira, A.; Nascimento, E. A.; Chang, R.; Borges, M. S.; de Melo, G. B.; da Silva, C. V.; Machado, F. C.; de Morais, S. A. L.; Chemical composition, antimicrobial, and antiprotozoal activity of essential oils from Vernonia brasiliana (Less) Druce (Asteraceae). Journal Essential Oil-Bearing Plants 2015, 18, 561. [CrossRef]

15. Case, R. J.; Franzblau, S. G.; Wang, Y.; Cho, S. H.; Soejarto, D. D.; Pauli, G. F.; Ethnopharmacological evaluation of the informant consensus model on anti-tuberculosis claims among the manus. Journal Ethnopharmacology 2006, 106, 82. [CrossRef][PubMed]

16. Justino, A. B.; Miranda, N. C.; Franco, R. R.; Martins, M. M.; Silva, N. M. D.; Espindola, F. S.; Annona muricata Linn. leaf as a source of antioxidant compounds with in vitro antidiabetic and inhibitory potential against alpha-amylase, alpha-glucosidase, lipase, non-enzymatic glycation and lipid peroxidation. Biomedicine \& Pharmacotherapy 2018, 100, 83. [CrossRef] [PubMed]

17. Dias, A. L. B.; Batista, H. R. F.; Estevam, E. B. B.; Alves, C. F.; Forim, M. R.; Nicolella, H. D.; Furtado, R.A.; Tavares, D. C.; Silva, T. S.; Martins, C. H. G.; Miranda, M. L. D.; Chemical composition and in vitro antibacterial and antiproliferative activities of the essential oil from the leaves of Psidium myrtoides O. Berg (Myrtaceae). Natural Product Research 2019, 33, 2566. [CrossRef] [PubMed]
18. Sartoratto, A. L. M; Machado, C. D.; Figueira, G. M.; Duarte, M. C. T.; Rehder, V. L. G.; Composição e atividade antimicrobiana de óleos essenciais de plantas aromáticas usadas no Brasil. Brazilian Journal of Microbiology 2004, 35, 275. [CrossRef]

19. Granados-Chinchilla, F.; Villegas, E.; Molina, A.; Arias, C.; Composition, Chemical Fingerprinting and Antimicrobial Assessment of Costa Rican Cultivated Guavas (Psidium friedrichsthalianum (O. Berg) Nied. and Psidium guajava L.) Essential Oils from Leaves and Fruits. Natural Product Chemistry \& Research 2016, 4, 1. [CrossRef]

20. da Silva, E. A. J.; da Silva, V. P. C.; Alves, C. F. J.; Alves, M.; Souchie, E. L.; Barbosa, L. C. A.; Harvest time on the content and chemical composition of essential oil from leaves of guava. Ciência Rural 2016, 46, 1771. [CrossRef]

21. Pimentel, F. A.; Cardoso, M. G.; Andrade, M. A.; Zacaroni, L. M.; Guimarães, L. G. L.; Influence of drying on the yield and chemical composition of volatile compounds from roots of Piper piscatorum trel. \& Yunck. (Piperaceae). Química Nova 2012, 35 , 715. [CrossRef]

22. Carneiro, F. B.; Júnior, I. D.; Lopes, P. Q.; Macêdo, R. O.; Variação da quantidade de $\beta$-cariofileno em óleo essencial de Plectranthus amboinicus (Lour.) Spreng., Lamiaceae, sob diferentes condições de cultivo. Revista Brasileira de Farmacognosia 2010, 20, 600. [CrossRef]

23. Fothergill, A. W.; Sutton, D. A.; McCarthy, D. I.; Wiederhold, N. P.; Impact of new antifungal breakpoints on antifungal resistance in Candida species. Journal Clinical Microbiology 2014, 3, 994. [CrossRef] [PubMed]

24. Cordeiro, R. A.; Alencar, L. P.; Brilhante, R. S. N.; CasteloBranco, D. S. C. M.; Teixeira, C. E. C.; Macedo, R. B.; Lima, D. T.; Neto, M. P. A.; Monteiro, A. J.; Alves, N. D.; Oliveira, M. F.; Sidrim, J. J. C.; Gadelha, M. F. R.; Antifungal susceptibility of emerging opportunistic yeasts and yeast-like fungi from $R$ hea Americana. Canadian Journal of Microbiology 2013, 59, 577. [CrossRef][PubMed]

25. Furlaneto, M. C.; Rota, J. F.; Quesada, R. M. B.; FurlanetoMaia, L.; Rodrigues, R.; Oda, S.; de Oliveira, M. T.; Serpa, R.; de França, E. J. G.; Species distribution and in vitro fluconazole susceptibility of clinical Candida isolates in a Brazilian tertiarycare hospital over a 3-year period. Revista da Sociedade Brasileira de Medicina Tropical 2011, 44, 595. [CrossRef] [PubMed]

26. Sieniawska, E.; Sawicki, R.; Swatko-Ossor, M. A.; Napiorkowska, A. P.; Ginalska, G.; Augustynowicz-Kopec, E.; The effect of combining natural terpenes and antituberculous agents against reference and clinical mycobacterium tuberculosis strains. Molecules 2018, 23, 176. [CrossRef] [PubMed]

27. Sikkema, J.; Bont, J. A.; Poolman, de B.; Mechanisms of Membrane Toxicity of Hydrocarbons. Microbiological Reviews 1995, 59, 201. [CrossRef] [PubMed]

28. Younis, Y.; L Street, J.; Waterson, D.; Witty, M. J. K. C. CellBased Medicinal Chemistry Optimization of High Throughput Screening Hits for Orally Active Antimalarials. Part 2: Hits from SoftFocus Kinase and other Libraries. Journal Medicinal Chemistry 2013, 56, 7750. [CrossRef] [PubMed] 
29. Rottini, M. M.; Amaral, A. C. F.; Ferreira, J. L. P.; Silva, J. R. A.; Taniwaki, N. N.; de Souza, C. S. F.; d'Escoffier, L. N. F.; Almeida-Souza, D. J. H.; da Costa, S. C. G.; Calabrese, K. S.; In vitro evaluation of (-)- $\alpha$-bisabolol as a promising agent against Leishmania amazonensis. Experimental Parasitology 2015, 148, 66. [CrossRef] [PubMed]

30. Baldissera, M. D.; Grando, T. H.; Souza, C.F.; Cossetin, L. F.; Sagrillo, M. R.; Nascimento, K.; da Silva, A. P.; Lana, D. F. D.; da Silva, A. S.; Stefani, L. M.; Monteiro, S. G.; Nerolidol nanospheres increases its trypanocidal efficacy against Trypanosoma evansi : New approach against Diminazene aceturate resistance and toxicity. Experimental Parasitology 2016, 166, 144. [CrossRef] [PubMed]

31. Soares, D. C; Portella, N. A.; Ramos, M. F. S.; Siani, A. C.; Saraiva, E. M.; Trans-caryophyllene: an effective antileishmanial compound found in commercial Copaiba Oil (Copaifera spp.), Evidence Based Complementary Alternative. Medicine 2013, 2013, 1. [CrossRef] [PubMed]

32. Maia, A. I. V.; Torres, M. C. M.; Pessoa, O. D. L.; de Menezes, J. E. S. A.; Costa, S. M. O. V. L. R. N.; Melo, V. M. M.; de Souza, E. B.; Cavalcante, M. G. B.; Albuquerque, M. R. J. R.; Volatile leaf oils of Vernonia brasiliana and Vernonia remotiflora: chemical composition and biological activity. Química Nova 2010, 33, 584. [CrossRef]

33. Vieira, T. M.; Dias, H. J.; Medeiros, T. C. T.; Grundmann, C. O.; Groppo, M.; Heleno, V. C. G.; Martins, C. H. G; Cunha, W. R.; Crotti, A. E. M.; Silva, E. O.; Chemical composition and antimicrobial activity of the essential oil of Artemisia absinthium (Asteraceae) leaves. Journal of Essential Oil Bearing Plants 2017, 20, 123. [CrossRef]

34. Rocha, E. O. L. C. S.; Cunha, M. V. S. G. S.; Freitas, T. R.; Nascimento, E. A., L. O. S.; Martins, C. H. G; de Aquino, F. J. T.; Chang, R.; Morais, S. A. L.; Antimicrobial activity of seasonal essential oils from Banisteriopsis malifolia (Ness \& Mart.) B. Gates. Revista Virtual de Química 2018, 10, 1562. [CrossRef]

35. Budovsky, A.; Yarmolinsky, L.; Ben-Shabat, S.; Effect of medicinal plants on wound healing. Wound Repair and Regeneration 2015, 23, 171. [CrossRef][PubMed]
36. de Araújo, F. F.; Neri-Numa, I. A.; de Paulo Farias, D.; da Cunha, G. R. M. C.; Pastore, G. M.; Wild Brazilian species of Eugenia genera (Myrtaceae) as an innovation hotspot for food and pharmacological purposes. Food Research International 2019, 121, 57. [CrossRef] [CrossRef]

37. Raut, J. S.; Karuppayil, S. M.; A status review on the medicinal properties of essential oils. Industrial Crops and Products 2014, 62, 250. [CrossRef]

38. Liu, Z.-Q.; Chemical methods to evaluate antioxidant ability. Chemical Reviews 2010, 110, 5675. [CrossRef][PubMed]

39. Arulselvan, P.; Fard, M. T.; Tan, W. S.; Gothai, S.; Fakurazi, S.; Norhaizan, M. E.; Kumar, S. S.; Role of Antioxidants and Natural Products in Inflammation. Oxidative medicine and cellular longevity 2016, 2016, 1. [CrossRef] [PubMed]

40. Diaz, P.; Jeong, S. C.; Lee, S.; Khoo, C.; Koyyalamudi, S. R.; Antioxidant and anti-inflammatory activities of selected medicinal plants and fungi containing phenolic and flavonoid compounds. Chinese Medicine 2012, 7, 26. [CrossRef] [PubMed]

41. Bodio, C.; Grossi, C.; Pregnolato, F.; Favalli, E. G.; Biggioggero, M.; Marchesoni, A.; Borghi, M. O.; Personalized medicine in rheumatoid arthritis: How immunogenicity impacts use of TNF inhibitors. Autoimmunity Reviews 2020, 19, 102509. [CrossRef] [PubMed]

42. Murdaca, G.; Negrini, S.; Magnani, O.; Penza, E.; Pellecchio, M.; Gulli, R.; Puppo, F.; Update upon efficacy and safety of Etanercept for the treatment of spondyloarthritis and juvenile idiopathic arthritis. Modern Rheumatology 2018, 28, 417. [CrossRef] [PubMed]

43. Zhou, M.; Xu, R.; Kaelber, D. C.; Gurney, M. E.; Tumor Necrosis Factor (TNF) blocking agents are associated with lower risk for Alzheimer's disease in patients with rheumatoid arthritis and psoriasis. PLOS ONE 2020, 15, 3. [CrossRef] [PubMed]

44. Kamatou, G. P. P; Viljoen, A. M.; A Review of the Application and Pharmacological Properties of $\alpha$-bisabolol and $\alpha$-bisabololrich oils. Journal of the American Oil Chemists' Society 2010 , 87, 1. [CrossRef] 